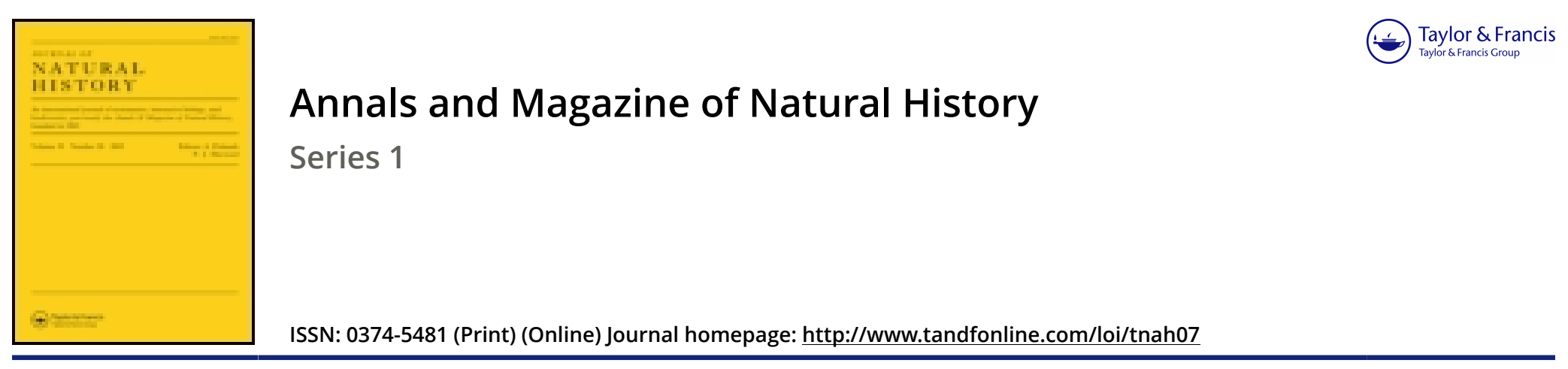

\title{
XX.-Note on the Occurrence of the Genus Diphya on the Coast of Ireland
}

\section{G. C. Hyndman Esq.}

To cite this article: G. C. Hyndman Esq. (1841) XX.-Note on the Occurrence of the Genus Diphya on the Coast of Ireland, Annals and Magazine of Natural History, 7:43, 164-166, DOI: 10.1080/03745484109442683

To link to this article: http://dx.doi.org/10.1080/03745484109442683

曲 Published online: 04 Dec 2009.

Submit your article to this journal $₫$

View related articles $\Longleftarrow$ 
results presented scarcely any remarkable difference. The physiological necdle was stuck in the spadix to the depth of one millimetre, which for this purpose was introduced through a copper ball fixed at an opening made in the jar, and moveable in all directions; which apparatus was made with the utmost accuracy by MI. E. Wenkebach, philosophical instrument maker at $\Lambda$ msterdam.

The analysis of the atmosphere produced the same results as in the former experiments, viz. the replacing of oxygen gas by carbonic acid gas.

As soon as an opportunity presents itself for the rcpetition of these experiments, we shall endcavour to maintain the usual proportion of the gases from the atmosphere in the jar, by supplying oxygen gas in the same ratio as it will be found to be absorbed from the enclosed air, and by removing the newlyformed carbonic acid gas.

We do not doubt, that by this mode of proceceling, the elevation of temperature in the spadix of Colocasia odlora can be kept up the second and third day, and perhaps eren to a longer period.

Amsterdam, August 13th, 1810.

XX.-Note on the Occurrence of the Genus Diphya on the

Coast of Irelanel. By G. C. II Yridsis, Esq., Miember of the Natural History Socicty of I3elfast.

WinLst dredging in Belfast Bay on the 6th October, 1838, I had the pleasure of taking in a small towing-net, along with a number of Beroes, a specimen of the remarkable genus Diphya, Cur, the occurrence of which in the British sens is hithicrto unrecorded.

With Cuvier's definition of the genus the specimen exactly arreced, as it did with that of Blainville, cxeept that there werc no tecth round the aperture of the swimming cavity, as described by the latter author. 'This appearance instead arose from the extension of the acute ridges by which the body of the animal is formed, and which is indeed shown by the figures in Pl. V. of his 'Actinologic.' Referring for the specics to this work, to Eschscholtz's 'System der Acalephen,' to Comte's and to Gućrin's 'Illustrations of Cuvier's Règne Animal,' and to Jones's 'Outlines of the Animal Kingdom,' the only works in which I have had the opportunity of secing the genus represented, I find that my specimen differs in species fiom all in its more elongated form; I should therefore propose to name it 


\section{Dirmia elongata.}

Spec. Char. Both portions of similar form and nearly cqual size; the swimming cavity of cach likewise similar, and, as well as the nutritive organ, extending the whole length of the body.

The animal or animals when first taken were united, as shown in the sketch, the whole body being of a most beautiful transparency; so much so, that it was extremely clifficult to distinguish it in the clear sca-water. 'The only.coloured part was the long tentacular appendage, which was of a light reddish colour, and only to be seen in the larger individual. The motion of the Diphya through the water was coused by the contraction of an elongated cavity having an open round aperture fringed with what liad the appearance of a soft membrane without any cilix, by which contraction the animal was rapidly propelled through the watcr with the pointed end foremost in a series of jerks, agrecing with the motion attributed to the genus by Eschscholtz. At other times, when lying undisturbed, there was no appearance of animation except a very slight movement of the tentacula, nor was the circulation perceptible under a strong lens; but on cxamination under a powerful microscope, a circulation was discovered commencing in the canal which originates at the base of the tentacular appendage, and continuing throughout the nutritive organ.

In removing the Diplyy for examination in the microscope the two bodies separated, when cach appeared quite a distinct animal, capable of preciscly similar motions; the only difference between them being, that the smaller one was destitute of the tentacular appendage, and the pointed end was furnished with a lamina, as in sketch.

Of the nature of the connexion between the two individuals, or of the functions of the tentacular appendage, I was unable to satisfy myself during the short period allowed me for their examination; the smaller one having died the day after its separation, and the larger one having remained in a languid state, with its tentacula contracted, until the third day after its capture, before which time I had not the means of cxamining it under a good microscope.

I have delayed this communication so long in the hope of being able to procure further specimens, but as yet I have been unsuccessful; although the probability is, that the animal may not unfrequently be met with on this coast, as Mr. 'Thompson lately pointed out to me a dricd specimen of another individual of the same species, which I had picked up 
166 Meyen's Report for 1839 on Physiological Jutany.

on the coast near the Giant's Causcway in July 1837, and not being able to determine, had handed over for his investigation.

Fig. 1.

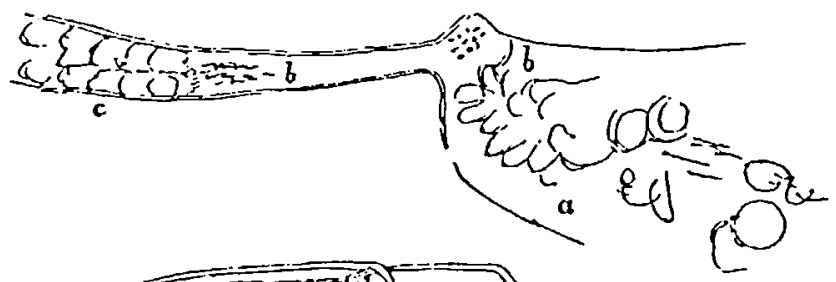

Fig. 2.

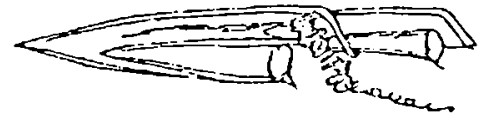

Fij. 3 .

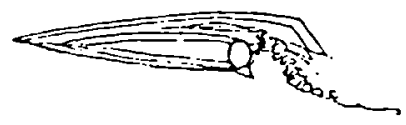

Fig. 4 .

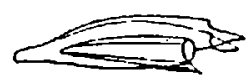

Fig. 1. A highly magnified view of the base of the tentacular appendage and part of the nutritive organ. $b, b$. Groups of opake particles in motion at these places, the circulation going on throughout the divisions of the oblong vessel $c$.

Fig. 2. The two animals united, as first taken.

Fig. 3. The larger individual with the tentacular appendage.

Fig. 4. The smaller individual.

When vieved under alens, the ridges of the body are seen to be scrrated along the edge.

XXI.-Report of the Results of Researches in Physiological Botany made in the year 1839. By F. J. Meres, MI.D., Professor of Botany in the University of Berlin*.

[Continued from vol. vi. p. 429.]

M. UXgen, in a treatise on the organs of fructification of Riccia glaucat, has made a few but very important remarks on the present question concerning the sexuality of Phanero-

* Translated from the Gcrman, and communicated by IIenry Croft, Esq.

+ Linnxa von $1830, \mathrm{pp}$. 15-17. 